\title{
A concepção de vida em Gregório de Nissa Ensaio de aproximações com as ciências da vida
}

Lina Boff e Eva Aparecida Rezende de Moraes

\section{Introdução}

Este artigo busca ser - como o próprio título indica - uma tentativa de leitura interdisciplinar sobre a vida, priorizando, neste exercício, a teologia e algumas ciências - como a biogênese, por exemplo. Nós, as autoras, acreditamos na possibilidade de convivência e, inclusive, de diálogo, entre fé e ciência. Acreditamos que, em muitas situações, fé e ciência andam lado a lado, possuindo o mesmo objeto, mas diversificando-se em seus métodos de pesquisa e intencionalidades. É acreditando nessa possibilidade real que escrevemos esse artigo.

Perseguindo esse objetivo, buscamos, assim, um campo epistemológico comum às ciências teológicas e científicas. Encontramos alguns interessantes entrelaces, mas optamos pelo tema da vida. Ele é um campo comum de pesquisas, tanto para a teologia, quanto para as ciências. Perguntas existenciais - como: Quem somos nós?, De onde viemos?, Para onde vamos?, Qual o sentido da vida?, Qual a finalidade da morte? - Fazem parte da cotidianidade humana e, portanto, são objeto de pesquisa teológica, científica e tecnológica.

Realmente, a revelação bíblico-cristã nos informa que Deus é vida. Mais que isso: Deus é amor! Portanto, se Deus é vida, é vida "boa", vida com sentido. Assim, ao longo das páginas da Tradição, encontramos essa definição e o desenvolvimento desse tema. Também para a ciência, a vida tem se revelado - principalmente nos últimos cem anos - um desafio e um 
encantamento. $\mathrm{O}$ avanço da tecnologia tem nos presenteado com descobertas fantásticas, desde o micro ao macrocosmo. Não é sem estranheza, portanto, que muitos cientistas têm adotado, para a vida, o sinônimo de "mistério".

Do ponto de análise teológico, encontramos inúmeras páginas da Tradição que tratam desse tema - a vida - desde a Bíblia aos dias de hoje. Filtramos, então, a pesquisa, a um ponto áureo e indiscutivelmente belo da Tradição cristã: a Patrística. Mesmo não sendo uma época de sistematização teológica - no sentido mesmo da palavra sistematização - a encontramos, entremeada de poética e simbólica, numa linguagem finamente rica e acessível à atualidade, em Gregório de Nissa. Esse eminente teólogo da Igreja nos presenteou com uma definição singela e profunda da vida, possibilitando, inclusive, um entrelace interdisciplinar com algumas das ciências conhecidas hoje como ciências da vida. Gregório de Nissa é um dos padres capadócios que se distinguiu como pensador original e teólogo ${ }^{1}$. É desse Padre que queremos nos ocupar no nosso artigo, extraindo das obras deixadas por ele, a concepção teológica de vida e como esta pode ser articulada com a concepção de vida na contemporaneidade.

O artigo consta de três partes: a primeira trará, rapidamente, aspectos biográficos e históricos, ora da Igreja, ora de Gregório de Nissa, ora da ciência, principalmente onde se aproximam. Na segunda, se abordará a concepção bíblico-teológica de vida de Gregório de Nissa, e, finalmente, na tercei$\mathrm{ra}$, as tentativas de aproximação entre as assertivas científicas - principalmente da atualidade - e a teologia de Gregório de Nissa.

Em nosso artigo, partimos do ponto de vista teológico: acreditamos que a Revelação e a fé oferecem o sentido para a existência da vida. Mas optamos, também, em dialogá-lo com recentes descobertas científicas, entremeando o texto onde encontrávamos uma proximidade interessante entre ambos os saberes. Tentamos conseguir, assim, articular o texto teológico com as ciências da vida, cuidando para que a linguagem científica se tornasse menos técnica possível - visto não ser esse o nosso objetivo. Em alguns momentos, uma aproximação foi possível, mas em outros não. Isto ficará bem evidente ao longo da leitura. Esperamos, sinceramente, que a sua leitura seja prazerosa, o tanto quanto foi para nós elaborarmos nosso ensaio.

\footnotetext{
${ }^{1}$ - Cf. BARR, R., Breve Patrologia, Brescia, Queriniana, p. 99-100. Gregório de Nissa, ativo entre 368-390, segundo dos grandes padres capadócios é denominado "o Teólogo". Pelo estilo eloquente de seus discursos de doutrina.. Conhecia bem a literatura grega e líder na polêmica anti-apolinista que negava a Cristo uma alma humana; ver também ALTANER, B., Stuiber, A., Patrologia. Vida, obras e doutrina dos Padres da Igreja, Rio de Janeiro, Lunen Christi, 2003, p. 306-311.
} 


\section{Primeira Parte:}

\section{Traços biográficos}

O século IV foi um tempo rico para a patrística, que já estava em ato desde o século III. Entre um século e outro corre uma corrente de continuidade e, ao mesmo tempo, de avanço. Esse avanço tem várias expressões. Aquela que se constituiu em um marco histórico da Igreja dos Padres Gregos se expressa no Concílio Ecumênico de Nicéia ${ }^{2}$, o qual se realiza em 325, quando, pela primeira vez, a Igreja Universal pronunciou uma definição dogmática, formalmente em sentido único, chamada evolução do dogma ${ }^{3}$.

O segundo grande padre capadócio, Gregório, foi bispo de Nissa, uma aldeia de pouca importância na Ásia Menor. Nasceu entre 335 e 340 e morreu em torno ao ano 394. Deixou várias obras, dentre as quais se destacam as de natureza bíblica. Por volta de 385-386, coloca-se uma obra de maturidade, a "Grande Catequese", suma doutrinal destinada aos mestres que, em suas instruções, precisam de um sistema. Partindo da "Grande Catequese", esse sistema consiste na meditada síntese teológica das doutrinas fundamentais examinadas e formuladas no Concílio de Constantinopla ${ }^{4}(381)$, e agora revisadas e formuladas nas categorias culturais do tempo do bispo nisseno 5 .

Segundo alguns autores e comentaristas dos padres capadócios, o bispo nisseno foi um dos pensadores mais originais que influenciou profundamente a espiritualidade oriental. A base do seu pensamento é quase exclusivamente bíblica ${ }^{6}$. Tímido e introvertido, revela-se na sua inteireza quando comenta textos bíblicos e cristológicos. O seu tratado sobre a perfeita figura do cristão, fundamenta-se numa série de textos cristológicos paulinos ${ }^{7}$.

\footnotetext{
2 - Cf. SESBOÜÉ, B., La divinitá Del Figlio e dello Spirito Santo, em Storia dei dogmi, I-VIII secoli, Monferrato, Piemme, 2000, p. 222ss. Gregório de Nissa se empenhou em discussões de grande rigor para ver em que sentido o Espírito era uma pessoa e qual o seu lugar no mistério trinitário. Suas investigações culminaram no Concílio Niceno-constantinopolitano em 381, com as afirmações: "Cremos no Espírito Santo, Senhor e Fonte da vida, que procede do Pai, que com o Pai e o Filho é conjuntamente adorado e glorificado e que falou pelos profetas". A Fé Católica. Documentos do magistério da Igreja, Rio de Janeiro, Lunen Christi, 2003.

3 - Cf. Patrologia III, BAC, Madrid, 1981, p. 41; 246; ALBERIGO, G., (org.), História dos Concílios Ecumênicos, S. Paulo, Paulus, 1985, p. 30ss.

4 - Cf. Storia dei dogmi, I-VIII secoli, o.c., p. 84, e, A fé Católica, o.c.

5 - La Gran Catequesis: introducción y notas de Mario Naldini. Traducción de Argemiro Velasco, Madrid, Ciudad Nueva, 1994: Introdución de la Gran Catequesis, $p .8$.

${ }^{6}$ - Cf. SARDI, P., La riflessione ecclesiale sui dati biblici, Monferrato, Marietti, p. 570-571.

${ }^{7}$ - Cf. Ibid., p. 570.
} 


\section{A concepção de vida entre os gregos e nos primeiros séculos cristãos}

Quando rastreamos a história da biologia, nos deparamos com uma antiga dicotomia entre substância (matéria, estrutura, quantidade) e forma (padrão, ordem, qualidade) ${ }^{8}$. Nos primórdios da filosofia ocidental - e, conseqüentemente, da ciência -, os pitagóricos distinguiam "número" (ou padrão) de substância (ou matéria): o padrão limitaria a matéria e lhe daria forma. Entretanto, Aristóteles - o primeiro biólogo da tradição ocidental - deu um passo adiante, ligando matéria e forma através do processo de desenvolvimento, enquanto Platão as separava. Aristóteles criou um sistema de lógica formal e um conjunto de concepções unificadoras, que aplicou às principais disciplinas da época (biologia, física, metafísica, ética e política).

Embora sem ligação histórica, o pensamento semita, que transparece da Bíblia, é tão unificador quanto o pensamento aristotélico - e, nesse sentido, podemos dizer que fé e ciência caminharam juntas. A visão bíblicounitária do ser humano - união corpo e alma, carne e espírito, pó e sopro encontra uma co-valência na visão aristotélica - matéria e forma. Entretanto, foi o pensamento platônico-dualista que influenciou os Padres dos primeiros séculos cristãos. Os padres dos primeiros séculos, até o $\mathrm{V}$, desenvolveram uma reflexão num ambiente de cultura, no qual confluíam componentes platônicas sobretudo, como também pitagóricas e estóicas. Existia uma decisiva atmosfera que desvalorizava o corpóreo, o somático, em nome de uma concepção dicotômica do ser humano.

Apesar disso, alguns padres da igreja dessa época - de modo especial os capadócios do IV século ${ }^{9}$ - não se deixaram induzir por essa concepção. Ainda que em meio tal influência, não abandonaram sua visão unitária da pessoa humana que os escritos bíblicos ofereciam a eles. Exemplificando, um texto patrístico do início do século III nos dá uma concepção da vida humana bastante iluminadora e eminentemente unitária da vida como um todo:

Deus chamou a carne mesma à ressurreição e the promete a vida eterna. Enquanto de fato anuncia ao ser humano a Boa Nova da salvação, anuncia-lhe esta Boa Nova à sua carne. Pois, que coisa é o ser humano se não um animal racional composto de uma alma e de um corpo? (...). O ser humano nasce da união do corpo e da alma; quando Deus chamou o homem à ressurreição e à vida,

\footnotetext{
8 - Cf. CAPRA, F., A Teia da Vida - "The web of life" -, São Paulo, Cultrix, 2002, p. 33.

9 - Cf. La gran catequesis de Gregório de Nisa: introducción y notas de Mario Naldini. Traducción de Argemiro Velasco, O.P., Madrid, Ciudad Nueva, 1994, p. 13-14; 52-53.
} 
não chamou uma só das suas partes, mas o homem total, isto é, a alma e o corpo ${ }^{10}$.

Textos como esse e outros terão tido grande influência não só em Gregório de Nissa, mas em todos os Padres que faziam suas reflexões, lançando as primeiras sementes de uma teologia - que só teria seu método próprio bem mais tarde - e uma hermenêutica que tinha a ver com o contexto vital e a vida de fé dos cristãos em geral.

Por quanto se refere à concepção gregoriana de vida, deve-se levar em consideração que, quando os padres dos primeiros séculos falavam da vida humana, eles entendiam falar da vida física. Segundo o pensar e o falar desses primeiros testemunhos de uma ainda incipiente teologia sobre a concepção da vida assim como se apresenta a nós hoje, esses testemunhos entendiam conceituar a vida no seu todo, com ênfase no sentido de vida humana física que Deus doou à criatura como imagem do Deus que se revela no Lo$\operatorname{gos}^{11}$. E foi essa vida, a vida humana, que Cristo veio arrancar do poder mortífero do pecado para que participasse da ressurreição. A ressurreição de Cristo plenifica a vida para a eternidade.

Nos séculos sucessivos, a reflexão teológica sofre influência da patrística e retorna às concepções fillosóficas de Platão e Plotino, aplicadas no século IV: chega a uma sistematização através do método analítico e discursivo, que abriu um amplo campo à especulação racional iluminada pela fé ${ }^{12}$. Essa teologia passa pela idade medieval, pela antropologia tomista com repercussões significativas.

Por quanto se refere ao mundo medieval este lia a realidade com base na filosofia aristotélica e na teologia cristã: tinha-se a noção de um universo orgânico, vivo e espiritual. Entretanto, pelos séculos XVI e XVII, essa visão mudou drasticamente: o mundo passou a ser visto como uma máquina, funcionando perfeitamente através de leis matemáticas - este foi o legado deixado pela chamada Revolução Científica, associada às descobertas em física, astronomia e matemática, feitas, entre outros, por Copérnico, Galileu, Descartes, Bacon e Newton $^{13}$. Foi adotado o método analítico, que consiste em "quebrar" fenômenos em "pedaços", buscando compreender o todo a partir das partes; o domínio da mente e o domínio da matéria foram vistos como independentes e separados. Esse modelo de leitura do universo - chamado "mecanicista" - foi aplicado também na biologia. Essa visão paradigmática

\footnotetext{
${ }^{10}$ - De resurrectione VIII, in Rouet de Journel, Enchiridion Patristicum, n. 147, p. 58-59.

11 - Cf. Patrologia, volume II dal concilio di Nicea a quello di Calcedônia, Roma, Marietti, 1976, p. 277-278.

12 - Cf., Sapientia Fidei, Introdução, BAC, Madrid, 1996, p. IXX-XX.

13 - Cf. CAPRA, F., ob. cit., p. 34 s.
} 
dominou a nossa cultura por centenas de anos: o universo como um sistema mecânico, o corpo humano como máquina, a vida em sociedades como competitiva pela existência, o progresso material como ilimitado, a mulher como inferior ao homem, entre outras ${ }^{14}$.

Porém, no início do século XX, ocorreram mudanças substanciais no pensamento científico - a exploração os mundos atômico e subatômico trouxe algo inesperado, e as concepções científicas básicas, vigentes até então, sua linguagem e seu modo de pensar, se mostraram inadequados para descrever tais fenômenos. A física, então, perdeu o seu lugar como ciência que fornece a descrição mais importante e fundamental da realidade - embora esse fato ainda não seja reconhecido por toda a comunidade científica; hoje, a mudança de paradigma no cenário da ciência implica uma mudança de rota: da física para as ciências da vida ${ }^{15}$.

No campo da teologia, filósofos e teólogos, ao longo dos séculos que se seguiram à idade patrística, deram sua contribuição, que nos dão fundamentos bíblicos, teológicos e históricos da vida, que tem sua origem da Fonte, que é Deus. Chegamos, assim, aos nossos dias - também no campo teológico, como foi no científico - com o compromisso de elaborar uma concepção de vida que expresse da melhor maneira a fé (teologia) que professamos no Deus como Fonte e Origem primeira da vida.

\section{A ousadia da inovação}

Vimos no tópico anterior que a visão mecanicista da realidade dominou o Ocidente durante séculos, comandada pela Revolução Científica; entretanto, o fato de ser hegemônica não significa ser isenta de oposição. A primeira visão ousada, opondo-se a essa visão, veio do movimento romântico - especialmente na arte, literatura e filosofia, no final do século XVIII e no século XIX ${ }^{16}$. Tal movimento concebia a forma como um padrão de relações dentro de um todo organizado - concepção que está na base do pensamento sistêmico contemporâneo. Essa visão romântica ajudou a ver a Terra como um todo integrado, um ser vivo - uma visão, aliás, de longa tradição, desde antigas histórias da religiosidade humana. Já no século XVIII, o geólogo James Hutton sustentava que os processos biológicos e geográficos estão todos interligados.

Igualmente no campo teológico, a tentativa de unir campos epistemológicos diferentes não é um empreendimento novo - já a notamos, por exemplo, em Gregório de Nissa, embora não possamos atribuir aos seus escritos à

14 - Cf. Ibid., p. 24-25.

15 - Cf. Ibid., p. 29.

${ }^{16}$ - Cf. Ibid., p. 35-36. 
consciência de que ele estivesse unindo teologia e ciências ligadas à vida. Seus escritos mostram, sim, sinais de influência platônica que o levam a uma originalidade muitas vezes "ousada" na elaboração e exposição de suas obras, sobretudo nos aspectos em que une filosofia e teologia ${ }^{17}$. Utiliza vastamente a filosofia em seu empenho por tornar mais acessível à inteligência humana os mistérios da fé.

A freqüência com que recorre ao saber considerado profano, no caso à filosofia grega pagã, desorientou alguns estudiosos do tempo de Gregório, a ponto de não valorizarem devidamente suas conquistas no campo teológico. Desse modo, interpretavam falsamente sua atitude essencialmente cristã e exageravam sua relação estreita que mantinha com Platão ${ }^{18}$. Gregório, contudo, sempre se deixou guiar pela tradição dos Padres. Assim expressa sua fidelidade a essa tradição:

Se é que a nossa racionalidade não se encontra à altura do problema, devemos manter sempre firme e imóvel [mas dinâmica na sua interpretação], a tradição que temos recebido dos Padres por sucessão (Quod non sint tres dii: PG 45, 117).

Pode-se perceber que, pelos escritos deixados pelo bispo de Nissa, e também pelos estudos e comentários sobre suas obras feitos por vários estudiosos, Gregório mantém sua autonomia própria diante dos textos da Sagrada Escritura; não separa a concepção de vida humana da concepção de vida cristã, a despeito das críticas que lhe são feitas por quase todos os autores clássicos que escrevem sobre ele ou comentam suas obras ${ }^{19}$.

\section{Segunda Parte:}

\section{A concepção de vida em Gregório de Nissa}

Recorridos os vários discursos ou sermões ${ }^{20}$ desse padre da igreja, traduzidos ou não e publicados em outras línguas, optou-se pela concepção de vida na sua dimensão humana cristã. A concepção de vida no sermão pronunciado por Gregório de Nissa na Páscoa da ressurreição de Cristo como

\footnotetext{
17 - La edad de oro de la literatura patrística griega, edición española preparada por Ignacio Oñatibia, Madrid, BAC II, 1985, p. 316.

18 - Cf. Los escritores del Asia Menor, BAC II, 1985, p. 317ss, que cita os estudos de: Gonazales, S., El realismo platônico de s. Gregório de Nisa, em Gregorianum 20 (1939), Paris, 189-206; e v. Balthasar, H. U., La philosophie religeuse de saint Grégorie de Nyse, Recherches de Science Religience, 1939, 513-549.

19 - Cf. QUASTEN, J., Patrologia II. La edad de oro de la literatura patrística griega, BAC, 1985, p. 283ss; do mesmo autor, La teologia dei padri, volume I, BAC, Cittá Nuova, 1985, p. 280ss; DROBNER, H. R., Manual de Patrologia, Barcelona, Herder, 1989, p. 303ss; OLIVAR, A., La predicación cristiana antigua, Barcelona, Herder, 1991, p. 94-100.

20 - As fontes consultadas utilizam as duas palavras como sinônimas.
} 
aquele que dá início à Nova Criação ${ }^{21}$, começa dando a concepção de vida na sua dimensão humana cristã. Elabora seu discurso em contexto Pascal com esse título: "O Primogênito da nova criação"22 - as leis do crescimento e a vida cristã. Por esta razão, ele afirma que, com a ressurreição, começou o reino da vida ${ }^{23}$.

A concepção de vida nesse discurso evidencia três elementos importantes para a vida humano-cristã. Tais elementos consistem num novo nascimento; numa nova vida; e num novo modo de viver. Falaremos de cada um a seguir, partindo sempre do discurso feito por ocasião do tempo Pascal, intitulado "O primogênito da Nova Criação e as leis do crescimento para a vida cristã", como também citaremos os comentários de outros teólogos contemporâneos sobre o mesmo discurso ${ }^{24}$.

\section{Vida: um novo nascimento}

Esse novo nascimento traz uma nova geração. Como mestre, nesse sermão, Gregório de Nissa começa por uma pergunta: quem é esta nova geração? E responde com palavras simples e diretas, fazendo uso da linguagem de figuras extraídas da própria criação.

Ele explica também como tudo isso acontece: o novo nascimento se dá através da nova prole concebida na fé (cf. Jo 1,13$)$ e regenerada pelo batis$\mathrm{mo}^{25}$. Tem como origem materna a Igreja, Comunidade de fé; como alimento, toma o leite de sua doutrina e das suas instituições a serviço. $\mathrm{O}$ autor fala também do alimento oferecido pelo pão da Eucaristia. O novo nascimento, portanto, cultiva um alto estilo de vida, porque o sacramento da Eucaristia leva a pessoa humana a atingir a maturidade humana e espiritual da nossa

21 - Cf. Oratio 1, in Christi ressurrectionem: PG 46, 603-606. 626-627, Primogenito della Nuova Creazione, in L'ora di lettura commentata dai padri della chiesa/4, Bologna, Dehoniane, 1976, p. 743 .

${ }^{22}$ - Aqui utilizamos à tradução da CNBB, Ofício das Leituras, vol. II, da quinta semana do tempo Pascal, segunda-feira, "O Primogênito da Nova criação", p. 742-743.

23 - Cf. GREGÓRIO nisseno, "La nostra stessa natura ha subito um cambiamento", in $V$. GROSSI (org.) e collaboratori varii, L'ora di lettura/4, o. c., p. 744.

23 - As fontes consultadas utilizam as duas palavras como sinonimas.

23 - Cf. Oratio 1, in Christi ressurrectionem: $P G$ 46, 603-606. 626-627, Primogenito della Nuova Creazione, o. c, p. 744.

23 - Cf. GREGÓRIO nisseno, "La nostra stessa natura ha subito um cambiamento", in $V$. GROSSI (org.) e collaboratori varii, L'ora di lettura/4, Bologna, Dehoniane, 1976, p. 743ss.

24 - Oratio 1, in Christi ressurrectionem: PG 46, 603.62-627, citado pela tradução da CNBB, em Liturgia das Horas, Ofício das Leituras, $5^{a}$. Semana da Páscoa, p. 743-744. Ver também o comentário feito pelo colaboradores de L'ora di lettura/4, citado acima: Le leggri della crescita e la vita cristiana; assim como o texto em língua italiana dos mesmos colaboradores, p. 358-360.

25 - Cf. Id., p. 743. 
vida cristã. As núpcias da geração provinda do novo nascimento trazido pela festa da Páscoa, se constituem na familiaridade dessa geração com a Sabedoria, que é empregada no sentido de manter intimidade com o Verbo ${ }^{26}$.

O bispo nisseno, aqui, nos levanta uma pergunta que tem a ver com o sentido do emprego que faz do Verbo intimamente relacionado com Cristo. Para ele, o Verbo é a Palavra do Pai, que vem a nós trazendo o próprio Deus que salva. $\mathrm{O}$ anúncio e o ensinamento de Jesus Cristo, portanto, é o próprio Senhor da vida que vem para salvar. O Pai se comunica com a humanidade através da Palavra que é Jesus Cristo, e que, pela sua intimidade com esse Pai, comunica a todos a salvação ${ }^{27}$. Para Gregório, o Verbo é aquele que vem beber conosco o vinho novo do reino de seu Pai, revelando definitivamente o que até agora só em parte nos mostrou ${ }^{28}$.

A nova Família que nasce da Páscoa tem como sua casa o reino de Deus; como filhos e filhas a esperança; e, como riqueza e herança, as alegrias do paraíso. Gregório dá um sentido de eternidade à palavra "paraíso" e fundamenta-a em textos no Novo Testamento ${ }^{29}$. É o que afirma nesta frase: o destino dessa nova Família, portanto, não é a morte, mas aquela vida eterna e bem-aventurada que é preparada para os que são dignos.

Gregório de Nissa emprega uma linguagem figurada para falar da integridade da vida humana. Para ele, esta vida é representada pelo sol que tudo ilumina e penetra; a boa terra é o coração humano; e, para falar da con-

\footnotetext{
${ }^{26}$ - La gran Catequesis, o.c., p. 62, V.3: "o Verbo é a Potencia de Deus e o Criador da natureza humana. Cria não por necessidade, mas por superabundância de amor para com o ser humano". Daí a Nova Criação. "Efetivamente, era necessário que a sua luz [de Cristo] não ficasse invisivel; nem sua glória sem testemunhas; nem sua bondade sem proveito; nem inativas todas as suas qualidades que contemplamos na sua divindade. Era necessário que estas qualidades do Verbo fossem participadas no mundo visivel".

${ }^{27}$ - Id., in L'ora di lettura commentata dai padri della chiesa/5, et alii, Soltanto il Verbo rivela pienamente il mistero di Dio, $p$ 298-299.

28 - Cf. Oratio 45, 23-24: PG 36, 654-655, in Liturgia das Horas/II da CNBB, p. 352.

29 - Cf. SEBASTIANI, L., Il paradiso terrestre, conferência proferida em Assis, Cittadella Editrice, posteriormente publicada em Rocca/7, 2004, p. 76-80. Ver também di SANTE, C., Il futuro dell uomo nel futuro di Dio, Torino, Elle Di Ci, 1994, p.139-40. O autor explica: o termo 'paraíso' é de origem persa e quer dizer jardim ou parque. Segundo a narrativa do livro do Gn 2, o mundo que Deus criou é um esplêndido jardim, que do hebraico e da Setenta esta palavra é traduzida como jardim. No NT esse termo aparece três vezes. Na boca de Jesus quando se dirige ao bom ladrão: "Hoje mesmo estarás comigo no paraíso" (Lc 23,43). Paulo quando fala de si mesmo: (... esse homem) foi arrebatado até o paraiso e ouviu palavras inefáveis que não é lícito ao homem repetir (2Cor 12,4). E pela terceira vez em João que atribui a Cristo as palavras: (...) ao vencedor, conceder-lhe-ei comer da árvore da vida que está no paraíso de Deus (Jo 2,7).
} 
duta nas relações entre os humanos e destes com toda a criação, toma a representação do ar que se respira, da atmosfera que nos envolve ${ }^{30}$.

$\mathrm{O}$ autor em estudo prossegue, fundamentando sua reflexão teológica em textos bíblicos do Novo Testamento. O mar e suas águas representam a riqueza; não só, mas representam também a sabedoria e a ciência (cf. Rm 11,33) que a nova geração desfruta para uma vida em abundância (cf. Jo 10,10). A Sagrada Escritura, para Gregório, não só fundamenta sua teologia, mas ela mesma é alimento para a vida como um todo: as ervas e as sementes que precisamos para o nosso alimento são doadas pela boa doutrina e pela palavra da Sagrada Escritura. Na Sagrada Escritura, a nova geração encontra o alimento como pastagem do rebanho, isto é, como povo de Deus a caminho. Não só, mas a prática dos mandamentos do Senhor está representada nas árvores frutíferas que todos podem pegar e comer ${ }^{31}$.

\section{Concluindo}

O novo nascimento, portanto, gera uma nova prole, que vive a comunhão entre si e com toda a criação plasmada pelo Criador. A concepção de vida humana cristã de Gregório de Nissa se dá dentro de uma concepção de fé que gera, que fecunda, que é fértil. A geração que nasce da fé é representada pelas coisas que o Criador do Novo Céu e da Nova Terra plasmou com o envio de seu Filho que inaugura a vida da Nova Criação. Compreende-se melhor o Livro da Revelação quando o escritor sagrado escreve: o primeiro céu e a primeira terra passaram e o mar já não existe (cf. Jo 5,1). Existe, sim, o mar com suas águas que representam a riqueza, a sabedoria e a ciência (cf. $\mathrm{Rm} 11,33$ ), que a prole do novo nascimento desfruta para uma vida em abundância (cf. Jo 10,10). Tudo isso traz uma nova vida.

\section{Vida: viver uma nova vida}

A nova vida trazida pela ressurreição de Cristo, sempre segundo o discurso do padre nisseno, se constitui no grande dia do Senhor. Toma o salmo 117 - que faz parte do hallel Pascal - para ressaltar a importância desse dia. Na tradição cristã, este salmo é aplicado ao dia da ressurreição de Cristo e utilizado na liturgia Pascal; caracteriza-se pelo louvor e ação de graças pelo dia em que o Senhor age, realizando maravilhas em favor de seu povo ${ }^{32}$ :

Este é o dia que o Senhor fez para nós, exultemos e alegremo-nos nele (Sl 117,24).

\footnotetext{
30 - Cf. Primogênito della nuova creazione, in L'ora di letttura/4, o. c., p. 359.

31 - Cf. Id., p. 360.

32 - di SANTE, C., Liturgia judaica. Fontes, estrutura, orações e festas, S. Paulo, Paulus, 2004, p. 219.
} 
Neste dia, é criado o ser humano à semelhança e imagem do Deus vivo, pois é a nova criação que começa ${ }^{33}$. Esta é diferente da primeira criação do mundo, medida pelo decurso do tempo. A criação desse novo dia destrói as dores da vida humana e da morte, pois é o dia em que Deus dá à luz o Primogênito dentre os mortos. Uma nova família nasce neste dia que o Senhor fez para nós. É a família da fé que o Filho Unigênito de Deus inicia e apresenta ao Pai para levar consigo cada um e cada uma de nós, que formamos os novos membros da sua família ${ }^{34}$.

O tema da ressurreição de Cristo enche as páginas da Igreja Antiga com a eloqüência e o entusiasmo próprios daquela época. Tratava-se de anunciar uma humanidade nova, nascida da vontade de Deus (cf. Jo 1,13), que, com o seu Espírito, ressuscitou seu Filho e o fez doador desse mesmo Espírito a toda a humanidade. Aqui está a grande novidade da chegada do Deus de Jesus Cristo na história humana: aparece uma nova vida, um novo modo de viver as relações; Deus entra na própria natureza da humanidade através de Jesus, o Enviado d'Ele. Diante de tal transformação da vida humana, o bispo de Nissa pergunta: Deus, então, subverte as leis normais da vida que nasce, cresce, se desenvolve e enfrenta as lutas e as dificuldades para atingir a maturidade?

No contexto dessa reflexão é que o bispo de Nissa explica, com figuras tomadas da criação ${ }^{35}$, como a transformação da vida humana cristã se dá. Avança em sua teologia, falando da criação de um novo céu e de uma nova terra - ávida da chuva que irriga, que produz abundantes feixes de espigas - e de um céu novo, que tem o firmamento da fé no ressuscitado. Esta vida tem os caracteres normais do crescimento de qualquer outra vida, também num contexto todo seu e próprio ${ }^{36}$.

\section{Concluindo}

Estudiosos e comentaristas dos discursos desse bispo escrevem que a fé cristã, do ponto de vista do cristianismo considerado como religião, pode até ser um processo de inserção que se dá como de improviso na vida humana. As suas leis, porém, são aquelas da semente - uma semente que, para crescer, necessita de tempo (cf. 1Pd 1,23). A vida cristã segue as leis de um caminhante, que faz seu caminho percorrendo uma estrada, que é mais longa

\footnotetext{
33 - Cf. RAHNER, K., Scienze naturali e Fede razionale, in Scienze e Fede cristiana, Nuovi Saggi 9, Roma, 1987, p. 65-66.

34 - Cf. O primogenito da nova criação, o. c.

35 - SANNA, I., Quale categoria di futuro? Associazione Teológica Italiana (A.T.I.), Padova, Messaggero 1995, p. 187-188.

${ }^{36}$ - Cf. O primogênito da nova criação, o. c., p. 744.
} 
do que a vida e que leva à ressurreição. Estas leis são próprias de cada pessoa, mas também de toda a comunidade de fé. Por esta razão, tanto a pessoa humana como a comunidade, já são santas, mas, ao mesmo tempo, ainda por santificar; já são crentes, mas, ao mesmo tempo, ainda por evangelizar, porque a fé é contínuo crescimento. Disso tudo irrompe um novo modo de viver a vida.

\section{Vida: um novo modo de viver}

Ao afirmar que a ressurreição de Cristo trouxe uma diferente geração porque a natureza assumiu uma grande mudança - a concepção de vida, para Gregório, se manifesta pelo fato de se apresentar como um modo de viver a vida baseado na relação. Esta relação é tratada entre a pessoa humana e Deus, como fonte de toda a relação. Entramos, aqui, no Comentário ao Cântico dos Cânticos ${ }^{37}$.

O comentário - que consta de quinze homilias do livro da Sagrada Escritura sobre o Cântico dos Cânticos, 1,1-6,8 ${ }^{38}$-, apresenta um prefácio, que defende a necessidade e o direito de dar uma interpretação espiritual à Escritura. No prólogo, Gregório tece grande elogio a Orígenes, do qual teve influência, sem, contudo, impedir sua autonomia e independência de pensamento filosófico e teológico ${ }^{39}$.

Sobre a relação da criatura com Deus e sobre a ação santificante do Espírito Santo, Gregório tem lá suas idéias. A tradição da igreja, porém, não hesitou em ler esses textos do nisseno à luz da relação do Deus vivo, plenamente revelado em Jesus Cristo, com sua criatura. Depois de haver conhecido Jesus Cristo, o ser humano - inspirado pelo mesmo Espírito - pôde dizer: Deus é amor ${ }^{40}$. Nesse caminho aberto por Orígenes e marcado pela interpretação de inumeráveis padres da igreja, segue Gregório. Interpreta, portanto, a busca da esposa do Cântico como a atitude da pessoa que crê, que confia, que se abre a uma relação com o Outro (Deus), e que descobre trazer dentro de si mesma um desejo de vida. Tal relação se manifesta numa aspiração

\footnotetext{
37 - Commento al Cântico dei cantici: PG 44,802, em l'ora di lettura commentata daí padri della chiesa / 8, Dehoniane, 1976, p. 372.

38 - Commento al Cantico dei cantici: $P G 44,802$, em l ora de lettura commentata dai padri della chiesa/ 8, Bologna, Dehoniane, 1976, p. 372.

39 - Cf. Patrologia, BAC volume II, p. 296, que cita el estúdio de C. Van Den Eynde, La version syriaque du Commentaire de Grégoire de Nysse sur le Cantique des Cantiques. Ses origenes, ses témoins, son influence, Lovaina 1939. Veja-se também LELOUP, J. Y., Introdução aos "verdadeiros filósofos". Os Padres Gregos: um Continente esquecido do pensamento ocidental, Vozes, 2003, p. 181-182.

40 - Cf. Patrologia volume II. Dal concilio di Nicea a quello di Calcedônia, Roma, Marietti, 1982, p. 269s.
} 
voltada para um mistério que a supera: o desejo do Deus vivo, Fonte de vi$\mathrm{da}^{41}$.

Nesse Comentário, o bispo de Nissa mostra a riqueza e a energia de seu pensamento, o percurso e as etapas do caminho da pessoa humana em direção à Realidade do desejo, Realidade da qual é sedenta. Segundo ele, o ser humano é um ser de desejo: desejo do Deus da vida, que lhe infundiu a raiz do divino no humano ${ }^{42}$. O bispo de Nissa mostra a riqueza e a energia de seu pensamento, assim como enfatiza, com vigor, o percurso e as etapas do caminho da pessoa humana, em direção à Realidade que ardentemente deseja atingir - mostra que o ser humano é um ser sedento desta Realidade: o Deus Uno e Trino. Como ser de desejo, o desejo do Deus da vida lhe infunde a raiz do divino no humano ${ }^{43}$. E termina, afirmando que as relações humanas nascem do conhecimento racional e cordial da relação profunda cultivada no interior de cada criatura, que se reconhece na imagem e semelhança do Deus Criador e Fonte de vida.

\section{Concluindo}

Daquilo que foi comentado acima sobre o novo modo de viver segundo os escritos de Gregório referidos ao Cântico dos Cânticos, podemos evidenciar dois pontos importantes: o primeiro trata diretamente da interpretação da relação humana do ponto de vista da fé ou seja, da relação que nasce da experiência da pessoa humana com Deus e seu mistério. O segundo ponto é conseqüência do primeiro: trata-se de estabelecer e criar relações humanas que nasçam da minha relação com o Senhor da vida que me re-cria continuamente e me dá condições de entrar em relação com os outros - porque me relaciono com Ele pela razão e pela fé, que formam o coração humano num coração divino.

\section{Terceira Parte:}

\section{Assertivas e aproximações}

Apresentaremos, nessa última parte, as assertivas científicas que mais se aproximariam da teologia de Gregório de Nissa, expressa, em parte, no seu sermão da Páscoa e no seu comentário do Cântico dos Cânticos. Evidentemente, $\mathrm{o}$ aspecto humano-cristão de vida foi mais explorado em Gregório, enquanto o aporte científico se deterá mais no aspecto humano-físico de

\footnotetext{
${ }^{41}$ - Cf. L'ora di lectura commentata dai padri della chiesa 8, Commento al Cantico dei Cantici, c. 2: PG 44, 802, elaborada por diversos autores, Bologna, Dehoniane, 1976, p. 372,

42 - LELOUP, J. Y., Introdução aos "verdadeiros filósofos", os Padres Gregos: um Continente esquecido do pensamento ocidental, o. c., p. 191.

${ }^{43}$ - Cf. Introdução aos "verdadeiros filósofos", o. c., p. 190-192.
} 
vida. Falaremos, assim, em dimensão de vida nos dois sentidos: estabelecer a extensão de seu significado para aquele contexto e para nós hoje, e descobrir a importância e o valor da vida como um todo, isto é, enquanto unidade da existência humana na qual a vida se manifesta.

As ciências perguntam: por que as coisas são como são? Assim, ela pergunta como é o universo, como se dão a vida, a morte, a evolução, quais as causas, como funciona tudo,..., e busca uma explicação, tanto para o estado atual quanto para os processos passados - e, por que não, futuros - do universo ${ }^{44}$. Por sua vez, a teologia pergunta e conhece a partir da fé. O caminho da teologia é tão ou mais problemático do que o das ciências ${ }^{45}$, visto que o conhecimento religioso não pode dispensar as outras formas de perguntar e de saber. Isso se chama diálogo interdisciplinar, uma espécie de mesaredonda, em que os diferentes conhecimentos, com seus métodos e suas investigações, são colocados juntos, para informar, confrontar, debater e encontrar novas profundidades de conhecimento. Entendemos que a interdisciplinaridade é uma exigência da nossa atual compreensão da realidade, na qual há uma complexidade de relações multicausais e multirreferenciais, em que tudo tem a ver com tudo, dentro de um paradigma holístico! O que segue abaixo é apenas um ensaio de resposta a essa exigência.

\section{Uma linguagem aproximativa}

Relatamos, anteriormente, uma mudança brusca - diríamos, paradigmática - na ciência dos inícios do século XX, provocada pela física. Tal mudança foi provocada pela pesquisa, tanto do microcosmo quanto do macrocosmo. É importante nos referirmos a ela, porque provocou o surgimento de uma reviravolta impressionante, não somente no conteúdo quanto no método e na linguagem científicos.

Novas, imensas e insuspeitadas descobertas da ciência estão desvendando um panorama absolutamente novo, inteiramente inimaginável, capaz de envolver o universo - desde o átomo até a galáxia - e o reino da vida desde a molécula até o organismo humano ${ }^{46}$. É um panorama imprevisto e imprevisível, surpreendente e inquietante, a um só tempo!

Há três séculos, a invenção do telescópio escancarou o universo: emergiram, dos abismos dos espaços siderais, miríades de estrelas e galáxias e a ciência encontrou-se perante o imensamente grande! Alguns decênios mais tarde, foi inventado o microscópio, e o vasto mundo dos micróbios, das

\footnotetext{
44 - Cf. SUSIN, L. C., A Criação de Deus, Coleção Teologia Sistemática, volume 5, Valencia (Espanha)-São Paulo (Brasil), Siquem Ediciones Catequéticas y Litúrgicas-Edições Paulinas, 2003, p. 23s.

${ }^{45}$ Cf. Ibid., p. 25.
} 
bactérias e das células vivas se desvendou aos nossos olhos - e a ciência encontrou-se perante o imensamente pequeno! Devemos nos habituar a viver num mundo imensamente mais complexo do que se apresenta aos nossos olhos e do que pode ser compreendido por nossa mente!

Não é de se admirar, portanto, que algumas ciências, hoje, venham adotando uma outra linguagem para explicar seus conceitos. Atualmente, existem três fatores que contribuem para o processo científico de descrição do mundo natural ${ }^{47}$ :

- A dedução (tentamos entender o mundo de dentro para fora, da mente para o mundo exterior);

- A indução (obtém medidas e dados que descrevem o mundo externo e procura criar de fora para dentro regras que organizam esses dados de forma lógica);

- O terceiro advém da insuficiência dos dois anteriores: o puramente dedutivo não pode explicar uma realidade que não conhecemos, e, o puramente indutivo, não explica quais dados são, de fato, importantes. $O$ terceiro fator (ou método) é a imaginação, a intuição, ponte entre o empírico e o racional.

Assim, hoje, podemos admitir que a melhor postura do cientista é estar atento para a descoberta de um fenômeno novo, isto é, ter a cabeça aberta para o inesperado. Ou seja: até um passado recente, o método experimental era compreendido como o único e fundamental para as ciências; entretanto, a partir do momento em que observamos comportamentos não totalmente explicáveis experimentalmente - como os do mundo atômico e subatômico, por exemplo - compreendemos que necessitamos da fantasia, da imaginação e da sensibilidade para compreendê-los e explicá-los.

Evidentemente, essa nova percepção científica aproxima mais ciências exatas e humanas, e utiliza uma linguagem mais acessível às pessoas. Tamanho é o impacto dessa mudança no campo científico, que percebemos, inclusive, alguns cientistas que já compreendem que é na totalidade e na complementaridade entre razão e espiritualidade que reside, hoje, a atração da visão científica do mundo ${ }^{48}$.

Historicamente, a ciência sempre teve o papel de oferecer explicações racionais para fatos e fenômenos que, sem ela, permaneceriam no terreno do medo e da superstição ${ }^{49}$. Mesmo que a origem do questionamento científico

\footnotetext{
${ }^{46}$ Cf. RAVALICO, D. E., A Criação não é um mito, São Paulo, Edições Paulinas, 1979², p. 5.

${ }^{47}$ Cf. GLEISER, M., Retalhos Cósmicos, São Paulo, Companhia das Letras, 2001, p. 42s.

${ }^{48}$ Cf. Ibid., p. 16. Como leitura complementar, temos, por exemplo: VV.AA., Mistica e ciencia, Coleção PSICOLOGIA TRANSPESSOAL, Volume 7, Petrópolis, Vozes, 1991.

${ }^{49}$ Cf. GLEISER, M., o. c., p. 46-47.
} 
tenha suas raízes profundamente entrelaçadas com a religião, a evolução da ciência foi marcada por um afastamento cada vez maior dessa origem: antes, o referencial da religiosidade, depois o da racionalidade! Finalmente, o palco das novas descobertas científicas do século XX trouxe uma possibilidade de re-aproximação entre os dois saberes - inclusive, através da nova linguagem científica, que inclui o sensível, o perceptível e o intuitivo.

Percebemos, no texto de Gregório de Nissa, uma linguagem teológicosimbólica, e, inclusive, feminina - principalmente quando discursa sobre uma nova geração, uma nova prole: geralmente, na natureza, quem gera é a mãe. Também alguns físicos, poeticamente, associam a geração do universo ao aspecto materno:

$$
\text { A mãe do Universo é a mãe de todas as histórias }{ }^{50} \text {. }
$$

Físicos - como Marcelo Gleiser - admitem que o apetite pelo saber racional e o senso de mistério, ao mesmo tempo, inspiram o pensamento religioso e estão na raiz de toda ciência ${ }^{51}$ - inclusive esse senso de mistério foi chamado, por alguns cientistas, de encantamento iônico ${ }^{52}$.

Os físicos, hoje, não conhecem experiências de espaço e tempo abaixo de certa distância minúscula e, portanto, ainda não conhecem todas as leis básicas: cada pedaço ou parte da natureza total é sempre uma mera aproximação da verdade completa, ou da verdade completa até onde é conhecida. Ou seja: nas ciências, atualmente, as coisas devem ser aprendidas para, às vezes, serem desaprendidas de novo ou corrigidas.

Assim, apesar do método experimental ter sido sempre o método científico, hoje, além das leis advindas do método, os físicos necessitam de imaginação para criar (fórmulas, teses, hipóteses,...), a partir das pistas elaboradas pelo método, as grandes generalizações. Portanto, existem atualmente duas categorias de físicos: os teóricos - que imaginam, deduzem e descobrem as novas leis - e os que experimentam ${ }^{53}$. E ambas as categorias - de experimentação e de teorização - são imprescindíveis, hoje, aos avanços das ciências.

\section{2. $O$ acento e a abertura ao novo}

Notamos, no sermão analisado de Gregório de Nissa, uma insistência na palavra "novo-nova". Também na ciência se discutiu, desde os primórdios, se a natureza permaneceria imutável, ou se geraria, se criaria o novo.

\footnotetext{
50 - Cf. NATALE, A. A.; VIEIRA, C. L., O Universo sem mistério, São Paulo, 2003, p. 11.

${ }^{51}$ Cf. GLEISER, M., o.c., p. 20 s.

${ }^{52}$ Homenageando os primeiros filósofos pré-socráticos que habitaram a Iônia, uma província grega na costa oeste da Turquia atual.

${ }^{53}$ Cf. FEYNMANN, R. P., Física em seis lições, Editora Ediouro, p. 36-37.
} 
Nos séculos VI a IV aC, Tales de Mileto possuía uma visão profundamente orgânica da Natureza como entidade dinâmica, em constante transformação, renovando-se indefinidamente em novas formas e criações, enquanto Parmênides acreditava exatamente no oposto: o que é essencial não pode se transformar - o que "é" simplesmente é (o físico Marcelo Gleiser detecta aqui o germe da idéia de uma entidade eterna, transcendente): nascia o debate entre o eterno e o novo, o "ser" e o "vir a ser" ".

Atualmente, sabemos que a natureza sempre se renova, é aberta ao novo, e sabemos disso através de descobertas impactantes, que têm nos deixado surpreendidos. A natureza surgiu da união entre átomos - uma união que formou as moléculas; descobrimos que existe um número imenso de moléculas na natureza, fruto de sua incrível versatilidade ${ }^{55}$ ! O físico Walter Elsasser cunhou o termo "imenso" para descrever números gigantescos, maiores do que $10^{110}$ - apenas para termos uma idéia: para calcular o número $10^{110}$, teremos que multiplicar o número 10 por ele mesmo cento e dez vezes! E o número de moléculas possíveis na Natureza é, certamente, "imenso"! Ele mostrou que, para armazenarmos as informações contidas numa lista contendo $10^{110}$ moléculas, precisaríamos de um computador cuja memória utilizaria todos os átomos de hidrogênio do universo! E, para examinarmos o conteúdo da lista precisaríamos de um tempo maior que a idade do universo - em torno de 15 bilhões de anos!

Enfim, existem moléculas que nunca foram estudadas, cujas propriedades são imprevisíveis (o número, por exemplo, de proteínas, de combinações genéticas, de tipos de célula ou de estados mentais são todos imensos): a Natureza é "imensamente" criativa! Ao aumentarmos o número de elementos em um sistema físico, aumentamos também as possibilidades de interação deles entre si e essas várias interações podem dar origem a comportamentos coletivos do sistema, que não poderiam ter sido previstos analisando apenas as interações individuais entre seus elementos. Isto é: novas leis são necessárias, visto que as tradicionais não conseguem dar conta da realidade!

Assim, nesta "nova ciência" que surge, o indicativo é o oposto do reducionismo: o uso de técnicas globais na descrição de sistemas ${ }^{56}$. Não dividir para entender, mas tratar o comportamento do todo como um todo! O todo é maior que a soma das partes! Essa nova ciência, com sua expansão do conhecimento, requer de nós muita paciência, tenacidade e humildade intelectual!

\footnotetext{
54 - Cf. GLEISER, M., o.c., p. 13.

55 - Cf. FEYNMANN, R. P., o.c., p. 16s.

${ }^{56}$ - Cf. Ibid., p. 32-33; 38.
} 
Voltando a Gregório de Nissa, notamos que ele se refere a um Novo Céu e uma Nova Terra. Segundo esse teólogo, a nova geração - perfeita -, é regenerada pelo batismo: uma nova "prole" amadurecida, humana e espiritualmente, pela Eucaristia. Podemos, então, compreender que Gregório possui uma idéia processual da vida cristã.

Encontramos aqui, também, uma aproximação com a ciência: em ciência experimental e observável, as explicações são sempre provisórias, ainda que extremamente eficientes por algum tempo. Entretanto, o fato de um modelo ser limitado não é necessariamente uma coisa negativa, pelo contrário: é justamente das limitações exibidas por um dado modelo que surgem novas idéias $^{57}$ ! Isto é: em ciência, imperfeição é a condição fundamental para o progresso! As limitações não querem dizer que o modelo está errado, mas, apenas, incompleto!

Essa afirmação pode jogar uma luz na reflexão teológica: a primeira geração - a plasmada por Deus - não é, necessariamente, imperfeita, mesmo devido a nossa condição de criaturas: é apenas incompleta, em processo, a caminho de uma plenificação, que virá com a Ressurreição do todo criado no Cristo, o Primogênito.

\section{A metáfora do sol}

Uma outra característica da linguagem teológico-simbólica de Gregório é a metáfora do sol como integridade da vida. Não somente ele, mas, desde os primórdios, a imagem do sol está, acertadamente, associada à vida.

O sol, para a ciência, é uma estrela, e é estudado pela cosmologia ${ }^{58}$. Parece incrível, mas até meados da década de 20, os astrônomos ainda não sabiam se a Via Láctea era a única galáxia no universo, ou se existiam outras - hoje, sabemos que existem centenas de bilhões de galáxias, cada uma delas com um número enorme de estrelas (sóis): um número que pode variar de milhões a centenas de bilhões! Decididamente, o nosso sol é apenas um, em meio a um número "imenso" de estrelas!

Sabemos hoje que a morte de uma estrela - ou sol - causa o nascimento de outra ${ }^{59}$ - ou seja: mesmo morrendo, um sol gera vida! Uma estrela - ou sol - é uma "bola de fogo", que passa toda sua vida lutando contra a sua gravidade, isto é: brigando para não morrer. Uma estrela - ou sol - é o resultado desse delicado equilíbrio entre implosão (para dentro de si) e explosão (para fora de si), que pode durar bilhões de anos. Sabemos que uma estrela como nosso sol vive cerca de 10 bilhões de anos (o nosso está em sua meia-idade);

57 - Cf. GLEISER, M., o.c., p. 41-42; 27-28.

58 - Cf. Ibid., p. 83.

59 - Cf. FEYNMAN, R. P., o.c., p. 105-106. 
para viver, a estrela tem que se autoconsumir, devorando desesperadamente suas entranhas de hidrogênio para balancear a enorme força de sua gravidade: ao acabar seu combustível, a gravidade faz com que ela imploda. Em geral, essa contração é seguida de uma expansão da estrela, expulsando enormes quantidades de matéria viva através do espaço interestelar. Essa matéria viva é o germe embrionário de outras estrelas e planetas. Nossos átomos de carbono, oxigênio e outros elementos químicos, que são sintetizados no interior das estrelas, através de reações nucleares, são ejetados das estrelas quando estas explodem, em eventos chamados supernovas.

Definitivamente, é muito apropriada a metáfora do sol associada à vida - pois, mesmo quando um sol morre, seu último ato é gerar vida! Tudo o que tem vida no universo foi gerado dos restos mortais de sóis; devido a isso, muitos físicos, poeticamente, afirmam que nós somos pós de estrelas!

\section{A metáfora do mar, da terra e das árvores frutíferas}

Uma outra metáfora cara a Gregório de Nissa é a do mar e suas águas, simbolizando riqueza, sabedoria, uma ciência que a nova geração desfruta para uma vida em abundância. Como no caso do sol, o mar, aqui, é muito associado à vida - e vida em abundância.

Também a ciência se ocupa com a vida que vem do mar. Aliás, juntamente com a questão da origem do universo, a origem da vida ocupa um lugar especial na vasta lista das questões em aberto em ciência. Duas idéias recentes acerca do surgimento da vida em nosso planeta têm despertado bastante discussão. A primeira, é que a vida teria vindo do espaço; essa teoria é baseada na presença de compostos orgânicos encontrados em asteróides ${ }^{60}$ presentes na Terra. A segunda, é que a vida na Terra surgiu nas profundezas dos oceanos primitivos, junto a fendas hidrotérmicas ${ }^{61}$. Mas, de qualquer forma que tenha surgido e se desenvolvido, a vida revela-se um acontecimento extremamente raro. Segundo os biólogos, a matéria viva é extremamente complexa, resultado de reações químicas, combinações moleculares e flutuações estatísticas muito improváveis - ou seja: a vida é um processo raríssimo ${ }^{62}$ !

Gregório de Nissa, em seu sermão, também utiliza a metáfora da terra: segundo ele, a terra é a imagem do bom coração, carregado de amor e afeto;

\footnotetext{
${ }^{60}$ - Asteróides são corpúsculos que viajam pelo espaço e, quando passam próximos à Terra, são atraídos pela gravidade de nosso planeta.

${ }^{61}$ - Pequenos vulcões submarinos que ejetam larva e calor.

${ }^{62}$ - Cf. CAPRA, F., O ponto de mutação - A ciência, a sociedade e a cultura emergente, São Paulo, Editora Cultrix, 2003, p. 259s.
} 
as árvores frutíferas do paraíso também são citadas, e estão, inclusive, ao acesso de todas as pessoas que delas necessitem.

Para as ciências, as pesquisas acerca da vida na terra são tão importantes quanto aquelas da vida surgida e desenvolvida no mar. Existem 92 elementos químicos estáveis na natureza, feitos de átomos; e, como nascemos da explosão de sóis, os mesmos elementos encontrados na Terra são encontrados em outras partes do universo ${ }^{63}$ - ou seja: o material de que é feita a Terra é o material do universo e vice-versa! Inclusive nós: somos feitos da mesma matéria de todo o universo! Mais uma vez, surge a idéia da unificação: todo o universo está em cada uma de suas partes e cada parte do universo porta a totalidade universal!

"Viajando" do macro ao microcosmo, nos deparamos, igualmente, com descobertas surpreendentes. Sob o microscópio eletrônico, por exemplo, descobrimos que uma folha de árvore é, metaforicamente, uma extraordinária metrópole produtiva, na qual reinam, soberanas, a organização e a cibernética: uma folha de árvore é cheia de automatismos, computadores e redes cibernéticas ${ }^{64}$. A tela fluorescente do supermicroscópio eletrônico nos revela que cada célula destas é como uma fábrica ultramoderna, inteiramente automatizada e em condições de funcionar sem nenhuma intervenção exterior e capaz de controlar a própria atividade, autodirigir-se. Seu diâmetro é de, apenas, um centésimo de milímetro, em média; no entanto, possui numerosos dispositivos que, metaforicamente, seriam seções de produção, cadeias de montagem e centrais energéticas! Porém, apesar de toda a sua autonomia, ela é incapaz de existir ou funcionar sem um centro diretor que coordene toda sua atividade, e de fornecer todas as indicações necessárias: é o seu núcleo.

Tais descobertas se iniciaram em 1675, graças a Marcelo Malpighi, fundador da ciência da vida, que perscrutou - com um dos primeiros microscópios - e conseguiu ver a estrutura íntima das plantas! Contudo, sua descoberta foi muito precoce e foi logo esquecida ${ }^{65}$ - talvez o mundo não estivesse preparado para recebê-la. Comparativamente, também Gregório de Nissa não foi muito bem compreendido pelos teólogos de sua época - a história, tanto da Igreja quanto da ciência, está repleta de testemunhos inovadores!

Mas, o mundo do muito pequeno revelou mais coisas! Por exemplo: que existe uma única fita DNA para todos os seres vivos, e a gravação é efetuada da mesma maneira para todos: seja de um líquen, de um carvalho,

63 - Cf. NATALE, VIEIRA, o.c., p. 20s.

${ }^{64}$ Cf. RAVALICO, D. E., o.c., p. 6-8.

${ }^{65}$ Cf. Ibid., p. 18. 
de um verme, de uma baleia azul $1^{66}, \ldots$ Na década de 1970 , a classificação dos seres vivos abrangia cerca de um milhão de espécies animais e 350.000 espécies vegetais; e existe um projeto e uma programação para cada um deles: varia a programação, mas a gravação é a mesma para todos! Foi com essa programação gravada na fita biológica do DNA que teve início a vida na Terra, e foi com essa programação que ela se difundiu no tempo, até nossos dias.

A fita DNA é imensamente fina - sua espessura é de apenas dois milionésimos de milímetro, igual a dez átomos. É também imensamente comprida - exatamente para conter a enorme gravação necessária para fornecer todas as indicações técnicas e as informações indispensáveis para construir um ser vivo. A fita de um micróbio é, em média, mil vezes mais comprida que o próprio micróbio: pode caber no micróbio, espiralada e enrolada, unicamente por ser imensamente fina. O DNA possui a programação completa de todo ser vivo, as indicações técnicas para que o ser vivo possa se autoconstruir e "funcionar"!

Realmente, como, poeticamente, dizia Gregório de Nissa: as árvores do paraíso estão ao alcance de todos! Todos os seres vivos - árvores, animais, nós - possuímos o todo em cada parte do DNA, e, inclusive, possuímos elementos comuns em nossa base de criação e geração.

\section{A metáfora da atmosfera e da família}

Gregório de Nissa cita, em seu Sermão da Páscoa, as metáforas do ar que respiramos e da atmosfera que nos envolve, relacionadas com a nova família: o ar que todos os seres vivos respiram simbolizaria as novas relações dessa grande família, formada da comunhão entre todos os seres vivos e seu Criador. Adiante, em seu Comentário do Cântico dos Cânticos, ele aprofunda a sua idéia de relação, a partir da Ressurreição de Cristo.

Segundo os estudos da biologia, a necessidade de respirarmos fora do mar fez com que a vida evoluísse nos animais - nesse sentido, segundo as ciências, nós surgimos da necessidade de respirar em terra firme.

No século XVIII, o pesquisador francês Jean-Baptiste Lamarck observou que os fatores ambientais podem modificar certas características dos indivíduos ${ }^{67}$. Assim, a necessidade de respirar na atmosfera teria feito aparecer pulmões nos peixes, que começaram a passar pequenos períodos fora d'água, o que permitiu a seus descendentes viver em terra mais tempo, fortalecendo os pulmões, e assim por diante: as brânquias, cada vez menos utili-

\footnotetext{
${ }^{66}$ Cf. Ibid., p. 16-17.

${ }^{67}$ - Cf. www.renascebrasil.com.br/f_criador2.htm. Resumo Extraído de Enciclopédias Projeto Renasce Brasil - www.renascebrasil.com.br.
} 
zadas pelos peixes pulmonados, terminaram por desaparecer. Estudos posteriores demonstraram que o postulado do lamarckismo estava correto: de fato, o ambiente provoca no indivíduo modificações adaptativas.

Interessante mesmo é a correlação feita por Gregório de Nissa entre o ar que respiramos e a relação entre os seres vivos: ambos são indispensáveis para a vida existir. E isto as ciências também vêm enfatizando. Fala-se, atualmente, numa filosofia quântica, uma nova forma científica de pensar a realidade, agora não mais detectável pura e simplesmente pelo método experimental.

A nova visão da realidade baseia-se na consciência do estado de interrelação e interdependência essencial de todos os fenômenos ${ }^{68}$ - numa linguagem teológica, comunhão. É uma visão que transcende as atuais fronteiras disciplinares e conceituais. Está se desenvolvendo uma abordagem bootstrap - isto é: uma formulação gradual de uma rede de conceitos e modelos interligados. Estamos, aqui, nos referindo à concepção sistêmica, que vê o mundo em termos de relações e de integração - os diversos sistemas são totalidades integradas, cujas propriedades não podem ser reduzidas às de unidades menores.

Um outro aspecto importante dos sistemas é sua natureza dinâmica: suas formas não são estruturas rígidas, mas manifestações flexíveis, embora estáveis, de processos subjacentes - ou seja: a vida vai acontecendo pela união entre os diversos processos do desenvolvimento dos organismos. A nova física está muito próxima dessa teoria geral dos sistemas, pois enfatiza mais as relações do que as entidades isoladas e percebe que essas relações são dinâmicas. Assim, reducionismo e holismo, análise e síntese, são enfoques complementares que, usados em equilíbrio, nos ajudam a chegar a um conhecimento mais profundo da vida.

A teoria geral dos sistemas - ou abordagem sistêmica - enfatiza os princípios básicos de organização; ela tem sido uma revolução no mundo científico que, antes, enfatizava os elementos ou as substâncias, isoladamente, sem estarem em correlação ${ }^{69}$. Hoje, sabemos que todo e qualquer organismo vivo é uma totalidade integrada - a natureza do todo é sempre diferente da mera soma de suas partes! Os organismos não são construídos - eles crescem, e devem ser entendidos como processos que refletem a organização dinâmica do sistema. Os organismos vivos mostram, também, um elevado grau de flexibilidade e plasticidade internas, e não há dois organismos que tenham peças rigorosamente idênticas. Embora o organismo como um todo

68 - Cf. CAPRA, F., O ponto de mutação, o.c., p. 259 s.

${ }^{69}$ Cf. Ibid. 
exiba regularidades e comportamentos bem definidos, as relações entre suas partes não são rigidamente determinadas!

A plasticidade e flexibilidade internas dos sistemas vivos dão origem a numerosas propriedades características, que podem ser vistas como aspectos diferentes do mesmo princípio dinâmico ${ }^{70}$. Este princípio é conhecido como princípio de auto-organização: sua ordem em estrutura e função não é imposta pelo meio ambiente, mas estabelecida pelo próprio sistema, que revela, assim, um certo grau de autonomia. Os dois principais fenômenos dinâmicos da auto-organização são a auto-renovação (os sistemas vivos se renovam sem perderem a integridade de sua estrutura global) e a autotranscendência (capacidade de se dirigir criativamente para além das fronteiras físicas e mentais), nos processos de aprendizagem, desenvolvimento e evolução.

Deste ponto de vista, determinismo e liberdade são conceitos relativos: na medida em que um sistema é autônomo em relação ao seu meio-ambiente, ele é livre; mas, na medida em que depender dele através da interação contínua, sua atividade será modelada por influências ambientais. Numa linguagem teológica, diríamos que o ser vivo - gerado por Deus - traz Sua marca de singularidade, mas uma singularidade relacionada!

A descoberta de que tudo o que existe na natureza é inter-relacionado tem provocado uma equivalente correlação entre os saberes das diversas ciências; por sua vez, essa integração entre os diversos saberes já está provocando o desenvolvimento de uma situação correspondente nas organizações sociais: a vida e os seres vivos somente se preservarão, se aprendermos a viver em inter-relação mútua - em comunhão.

Assim, esse novo estado de coisas - a vida completamente interligada e correlacionada - se coaduna com a metáfora da família utilizada por Gregório de Nissa, quando explica que, com a festa da Páscoa, temos o nascimento da Nova Família. Esta Nova Família tem como sua casa o Reino de Deus; como filhos e filhas, a esperança; e, como riqueza e herança, as alegrias do céu eterno, que começa já aqui.

Sonhamos e buscamos construir o estabelecimento de uma responsabilidade mundial, uma ética planetária, a partir das quais o todo não é uma soma funcional de partes - visto que cada parte é única, livre, autônoma e imprescindível - mas a comunhão fraterna e de irmandade dos diferentes, dos distintos, os quais trazem a marca de seu Criador. Caminhamos, em ascendência processual, para essa maturidade da vida, na qual a ascensão humano-cristã se faz imprescindível.

\footnotetext{
${ }^{70}$ Cf. Ibid.
} 
Cristo é o Protótipo por excelência desse estado de coisas, dessa relação fundamental - de onde tudo veio e para onde tudo vai. "Ele é a Imagem do Deus invisível" $(\mathrm{Cl} 1,15)$, gerado antes de toda a criação no sentido do Desejo de Deus. Cristo preside esse Desejo. "Nele foram criadas todas as coisas" $(\mathrm{Cl} 1,16)$. A criação se situa sob o signo da encarnação. $\mathrm{O}$ mundo toma em Cristo uma unidade de origem e de destino. A protologia cósmica implica uma escatologia salvífica. Pois, "Ele é antes de tudo e tudo nele subsiste" $(\mathrm{Cl} 1,17)$.

\section{Conclusão}

O bispo nisseno sobressai pela sua exposição orgânica da fé cristã, pelas especulações doutrinais e pelo seu alcance teológico, que superam as controvérsias de seu tempo e representam uma contribuição significativa ao desenvolvimento da teologia como tal. A teologia gregoriana afirma que a inteligência humana dos mistérios da fé passa pelo vasto conhecimento da filosofia que ele cultiva, com a finalidade de tornar acessível e inteligível o conhecimento dessas verdades. Estas explicitam a origem primeira da vida humana e fundam esta vida humana na vida divina. Compara a filosofia com a esposa do Cântico dos Cânticos, porque ensina como sermos criaturas fecundas na dinâmica da vida, cujos frutos dão identidade humano-cristã a cada pessoa.

Encontramos, partindo da teologia de Gregório de Nissa, aproximações interessantes - das quais este artigo não deu conta - com algumas asserções das atuais descobertas das ciências da vida. Essa proximidade deu-se historicamente, visto que encontramos entrelaces de inovações ousadas, tanto na história da Igreja - da qual Gregório e nós fazemos parte -, quanto na história da ciência. Por outro lado, encontramos, igualmente, tais entrelaces inovadores entre os conteúdos da teologia gregoriana e os das descobertas científicas.

Concluímos, descobrindo que a teologia de Gregório de Nissa se antecipa à evolução da ciência: ela diz antes, com figuras, o que a ciência disse posteriormente. Porém, a ciência - devido à facilidade do aparato tecnológico - avança mais rapidamente que a teologia gregoriana nas suas conclusões acerca da vida. Por sua vez, o que interessa à teologia como um todo não é a rapidez, mas a firmeza e a constância das suas afirmações, em consonância com a Revelação, sempre presente, de Deus, o Criador, e plena em Cristo, o Protótipo da Nova Criação. 


\section{Resumo}

Parte-se dos escritos de Gregório de Nissa considerado místico e teólogo da patrologia grega, na Ásia Menor. O estudo procura extrair sua concepção de vida humana cristã e de vida eterna. Esse artigo se detém na concepção de vida humana cristã, deixando para outra ocasião a concepção de vida eterna do bispo nisseno. A linguagem simbólica e algumas vezes poética de Gregório de Nissa, nos levou a uma tentativa de leitura interdisciplinar da teologia gregoriana, na qual encontramos aproximações interessantes com as ciências da vida.

\section{Resume}

On part des écrits de Grégoire de Nisse, le renomé mystique et théologien de la patrologie grecque dans l'Asie Mineure. L'étude cherche extraire de ces textes une conception de vie humainne chrétienne et de vie éternelle. Dans cet'article on développe la conception de vie humaine chrétienne, en laissant à une prochainne opportunité la conception de vie éternelle chez l'évèque nissin. Le langage théologique de Grégoire de Nisse, symbolique et quelquefois poétique, nous a porté à un essai de lecture interdisciplinaire, avec des rapprochements avec les sciences de la vie dignes d'íntérêt.

Lina Boff

Professora do Departamento de Teologia da PUC-Rio Pós-doutora pela Pontifícia Universidade de Roma

Eva Aparecida Rezende de Moraes

Doutora em Teologia pela PUC-Rio

Professora do Departamento de Teologia da PUC-Rio Professora do Instituto Teológico Franciscano de Petrópolis 